\title{
A Serious Disease of Groundnut Caused by Cowpea Mild Mottle Virus in the Sudan
}

\author{
S. M. El-Hassan', R. A. Naidu' ${ }^{2}$, A. H. Ahmed and A. F. Murant ${ }^{3}$
}

Authors' addresses: 'Department of Crop Protection, Faculty of Agriculture, University of Khartoum, Shambat, Sudan; ${ }^{2}$ Crop Protection Division, International Crops Research Institute for the Semi-Arid Tropics (ICRISAT) Asia Center, Patancheru (PO), India 502 324; ${ }^{3}$ Virology Department, Scottish Crop Research Institute (SCRI), Dundee DD2 5DA, UK (correspondence to R. A. Naidu)

With 4 figures

Received December 16, 1996; accepted February 28, 1997

\begin{abstract}
A serjous disease of groundnut (Arachis hypogaea L.) characterized by stunting of plants, downward rolling, mottling, general chlorosis and reduced size of the leaflets was observed in the Sudan. Surveys conducted from 1992 to 1994 showed that this disease was restricted to irrigated groundnut crops grown between the two Niles. The virus had slightly flexuous filamentous particles $(626 \mathrm{~nm}$ long) and was transmitted by whiteflies. It was identified serologically as cowpea mild mottle virus (CPMMV). This appears to be the first record of natural occurrence of CPMMV on groundnut in the Sudan and the first evidence that it causes a disease of major economic importance.
\end{abstract}

\section{Zusammenfassung}

Das Cowpea mild mottle virus als Erreger einer schweren Krankheit der Erdnufi im Sudan

Im Sudan wurde eine schwere Krankheit der Erdnuß (Arachis hypogaea L.) beobachtet. Sie äußerte sich durch folgende Symptome: kümmernde Pflanzen sowie nach unten eingerollte, gescheckte, chlorotische, auffällig kleine Blättchen. Von 1992 bis 1994 durchgeführte Untersuchungen zeigten, daß die Krankheit nur auf bewässerten Erdnußfeldern zwischen dem Weißen und dem Blauen Nil auftrat. Das Virus war leicht gebogen, fadenförmig und $626 \mathrm{~nm}$ lang. Es wurde durch WeiBe Fliegen übertragen und serologisch als Cowpea mild mottle virus (CPMMV) identifiziert. Dies ist offenbar der erste Bericht uber ein natürliches Vorkommen des CPMMV bei ErdnuB im Sudan und der erste Nachweis, daß dieses Virus eine wirtschaftlich sehr wichtige Krankheit verursacht.

\section{Introduction}

Groundnut production in Eastern Africa is dominated by Sudan, which accounts for $71 \%$ of the region's groundnut area and $66 \%$ of its production. Groundnut is an important cash and food crop in Sudan and is produced about $60 \%$ under rainfed and $40 \%$ under irrigated conditions (Mahmoud et al., 1992). The low yields of groundnuts have been attributed to several abiotic and biotic factors. including viral diseases. Disease surveys conducted in major groundnut-producing areas from 1992 to 1994 revealed the wide distribution of a disease different from the virus diseases previously reported from the Sudan (Ahmed and Idris, 1981; Ahmed, 1991). We present evidence that this disease is caused by a virus serologically related to cowpea mild mottle virus (CPMMV). This is the first report of CPMMV causing a disease of major economic importance.

\section{Materials and Methods}

Disease surveys were conducted mostly curing August to September when the crop was about 2-3 months old. Infected plants were tested for peanut stripe virus (PStV, now considered as a strain of bean common mosaic virus, Barnett et al., 1995), peanut mottle virus (PeMoV), peanut stunt virus (PSV) and CPMMV by using the direct antigen coating form of enzyme-linked immunosorbent assay (DAC-ELISA) as described by Hobbs et al. (1987). Antisera used in this study were from the following sources: ICRISAT, India (PStV, PeMoV and CPMMV), Dr A.A. Brunt, Horticulture Research International, UK (CPMMV) and Dr S.A. Ghabrial, University of Kentucky, USA (PSV).

Leaves sent to the Scottish Crop Research Institute were tested for groundnut rosette virus (GRV) by mechanical inoculation. Infected leaflets were triturated in $0.01 \mathrm{M}$ phosphate buffer, $\mathrm{pH} 7.2$, containing $0.02 \mathrm{M} 2-$ 
mercaptoethanol and inoculated to 2-week-old healthy groundnut seedlings, and to the following test plants: Chenopodium amaranticolor, C. quinoa, Nicotiana benthamiana and $N$. clevelandii.

The disease was established in a glasshouse $\left(25-30^{\circ} \mathrm{C}\right.$ ) by graft-inoculating healthy groundnut plants. Vector transmission tests were done with aphids (Aphis craccioora, A. gossypii) and whiteflies (Bemisia tabaci). They were allowed to feed on young leaflets showing clear symptoms for an acquisition access period of $1-24 \mathrm{~h}$ and then transferred to 10-day-old healthy groundnut seedlings for an inoculation access period of $24-48 \mathrm{~h}$.

Leaf-dip preparations were made by triturating leaflets in $0.01 \mathrm{~m}$ phosphate buffer, $\mathrm{pH} 7.2$, containing $0.04 \mathrm{M}$ $\mathrm{Na}_{2} \mathrm{SO}_{3}$. A droplet of the extract was transferred to 300mesh carbon-coated copper grids, stained with $1 \%$ uranyl acetate and examined in a Philips Model CM 10 electron microscope. Immunosorbent electron microscopy analyses of leaf samples were done with antisera to PStV. PeMoV, PSV and CPMMV. Virus particle morphology and modal length were determined by trapping the virus particles in crude extracts with CPMMV antiserum at 1:1000 dilution. Particles were stained and observed by electron microscopy as described above.

\section{Results and Discussion}

Under field conditions, infected plants appeared stunted with reduced internodal length and leaf size. A range of symptoms consisting of leaf mottling, general chlorosis, leaf size reduction and downward rolling were observed, depending on the cultivar (Figs 1,2 and 3). Plants infected early showed severe stunting and proliferation of axillary buds. Under greenhouse conditions. initial symptoms consisting of downward rolling and chlorosis along the veins appeared on newly developing leaflets $10-12$ days after inoculation (Fig. 2), Leaves developing subsequently showed mottling symptoms similar to those observed under field conditions. The disease was observed in groundnut grown under irrigated conditions between the two Niles but not in rainfed groundmuts in Western Sudan. The disease incidence was greater in late sown crops (early July) than in early sown crops (late

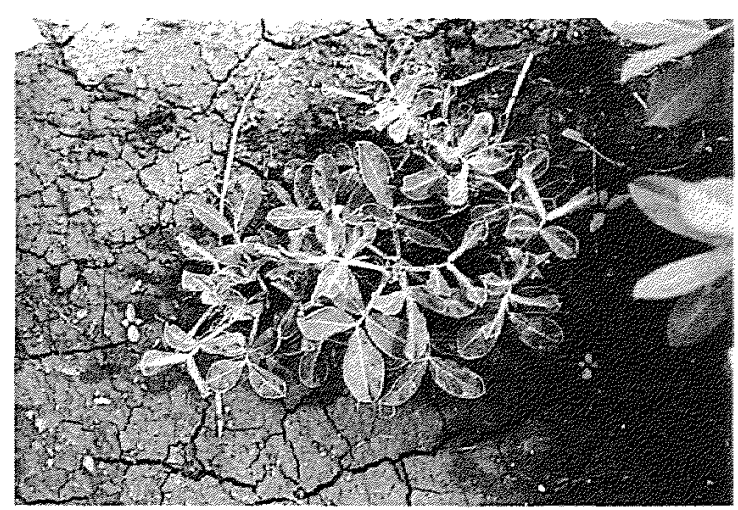

Fig. 1 An early infected groundnut plant showing stunting, downward curling of leaflets and mottling symptoms

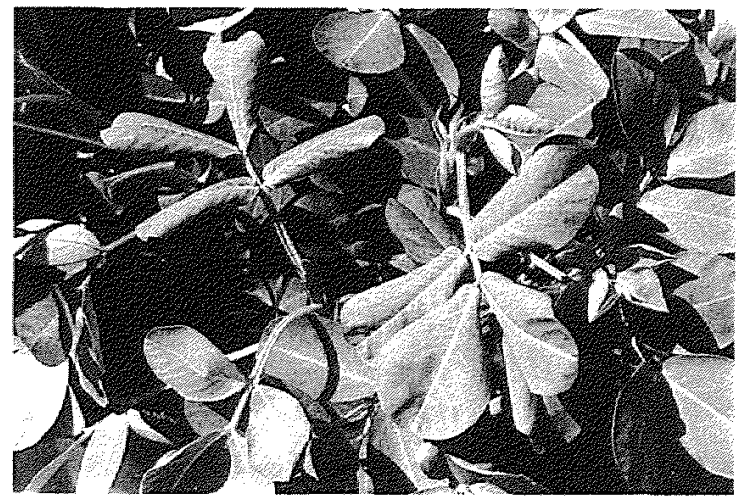

Fig. 2 A groundrut plan showing initial symptoms consisting of downward rolling and veinal chlorosis symptoms

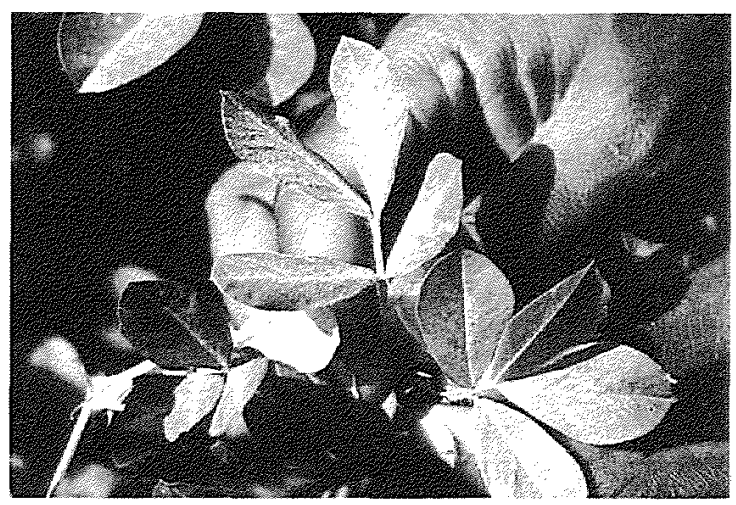

Fig. 3 Close up view of a groundnut leaflet showing mottling symptoms

May to early June). Over a period of 3 years, incidence usually ranged between 10 and $50 \%$, but in some fields amounted to $100 \%$. Selected fields were visited at regular intervals (biweekly) and plants with early (before fowering) and late infection (after flowering) tagged for yield estimates. Data showed that early infection gave no pods whereas infection after flowering caused yield losses up to $60 \%$.

In tests for GRV, the symptoms induced following mechanical inoculation of herbaceous test plants were unlike those of GRV (Reddy et al., 1985) but resembled those described for CPMMV (Brunt and Kenten, 1973), viz: large necrotic lesions of $23 \mathrm{~mm}$ in diameter in $C$. amaranticolor and $C$.quinoa, and a faint systemic chlorosis in $N$. clevelandii; no obvious symptoms were seen in $N$. benthamiana. In DAC-ELISA, samples collected from the field or greenhouse gave positive reactions with antiserum prepared against a CPMMV isolate infecting groundnut in India (lizuka et al., 1984) and a cowpea isolate from Ghana (Brunt and Kenten, 1973), but not with antisera to other groundnut viruses tested. These results were further confirmed in the immunosorbent electron microscopy tests in which the virus particles were trapped only with CPMMV antiserum. Electron microscopy of leaf-dip preparations revealed slightly 


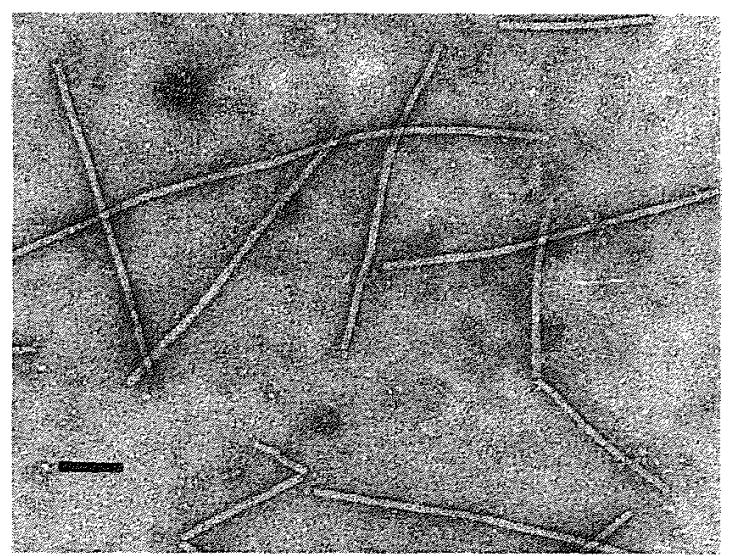

Fig. 4 An electron micrograph of flamentous virus particles. Bar represents $100 \mathrm{~mm}$

flexuous fitamentous virus particles (Fig. 4). These particles (100 measured) were $626+16 \mathrm{~nm}$ long and 16 I $2 \mathrm{~nm}$ in wide. The virus was transmitted by $B$. fabact but not by aphids (Aphis cracciora and A. gossypin) that transmit known groundnut viruses. The symptoms induced in plants inoculated mechanically or by whitefles were the same as those observed in the field and extracts from these plants reacted with CPMMV antiserum in ELISA.

Transmission of the Sudanese groundnut virus by $B$. tabaci further confrmed its identity as CPMMV which, though tentatively placed in the genus Carlawis (Brunt, 1995), differs from other Carlaviruses in being transmitted by this whitefy, and not by aphids. This is the first record of CPMMV from the Sudan, and of tis association there with a serious disease of groundnut. CPMMV was first described from Ghana, in cowpea (Brunt and Kenten, 1973), and was shown to infect groundnut experimentally. but the first reports of the virus occurring naturally in groundnut were from Kenya and Tanzania by Bock el al. (1975, 1977), who showed that it was related to the Ngomeni mottle virus of Storey and Ryland (1957). Natural occurrence of CPMMV in groundnut has also been reported from India (lizuka et al., 1984), Malaysia and Indonesia (lwaki et al.. 1986), Solomon Islands (Brunt. 1987) and Yemen Arab Republic (Walkey et al., 1990). A B. tabaci-transmitted virus with $6.650 \mathrm{~nm}$ filamentous particles occurring in Ivory Coast was called groundnut crinkle virus (GCV, Dubern and Dollet, 1981). Jeyanandarajah and Brunt (1993) slated that GCV is serologically related to CPMMV and is probably a strain of that virus. The extent of the relationship is unclear but there seem to be differences in host range: GCV is restricted to Leguminosae whereas both the Ghanaian (type) and the Sudanese isolates of CPMMV also infect such hosts as $C$. amaranticolor, $C$. quinoa and N. clevelandii. Moreover, CPMMV and GCV induce different symptoms in groundnut.

Bock and Wangai (1984) considered that CPMMV was responsible for the most serious disease of groundnut in eastern coastal regions of Kenya and our observations showed that CPMMV is responsible for a serious disease of groundnut in irrigated areas in the Sudan. Moreover, it is known to infect other leguminous crops that are important in the same area such as beans, cowpea, alfalfa and faba beans. Indeed, continuous growth of leguminous crops under irrigation would seem to provide ideal conditions for survival and spread of the virus. Thus, there is clearly a need for study of the economic importance, ecology and epidemiology of whitefy transmitted CPMMV and CPMMV-like viruses in food legumes in the semirid tropical countries of Africa. This is especially true in the context of increasing recognition of the importance of whitefly borne plant virus diseases in the tropics.

\section{Acknowledgements}

Part of this work was earred ou with mancial assistance from ICRISAT-DDG' Africa Fund. SCR is grantaided by the Scotish Office of Agriculure. Envmonnent and Fiskeries Department

\section{Literature}

A hmed, A. H. (1991): Virus diseases of groundnut in Sudan. In: Reddy D. V.R., D. MeDonald (eds). Groundnut virus diseases in Africa. pp. 21-22. ICRISAT. Patancheru. A.P. 502 324. India.

Ahmed, A. H. M. O. Idris (1981) Peanut motte virus in the Sudan. Plant Dis. 65, 692-693.

Barnett. O. W.. G. Adam, A. A. Brunt, J. Dijkstra. W. G, Dougherty J. R. Edwardson, R. Goldbach, J. Hammond, J. H. Hill, R. L Jordan. S. Kashnwakak. S. A. Lommel. K. Makkouk. F. J. Morales, S. T. Ohki. D. Purcifull. D. D. Shukla, I. Uyeda (1995): Family Potyviridae In: Murphy, F. A. C. M. Fauquet, D. H. L. Bishop, S A. Ghabrial, A. W. Jarvis. G. P. Martelli, M. A Mayo, M. D Summers (eds). Virus Taxonomy--The Classification and Nomenclaiure of Vifuses: Sixth Report of the International Commintee on Taxonomy of Virases. Arch Virol (Supl 10) pp. 348-358

Bock. K. R. E. J Guture G. C. Meredith. J. G. M. Nuguna (1975) Groundnut viruses. Report of the East African Agticulture and Forestry Research Organization for 1974, p. 120.

Bock. K. R. E. I Guthrie G. C. Meredith J. G. M. Nuguna (1977): Groundnut viruses. Report of the East African Agriculture and Forestry Research Organization for $1975, \mathrm{p}, 117$.

Bock. K. R., A. Wangai (1984): Cowpea mild motte virus in groundnut. Record of Reseanch Kenya Agricultural Research Instimute 1977 $1980,190-192$

Brunt. A. A. (1987): Surveys for plant viruses in Solonon Islands. UNDP FAO and SPC Report. p. 15

Brun, A. A. (1995): Genus Carlatirss. In: Murphy, F. A.. C. M Fauquet, D. H. L. Bishop. S. A. Ghabrial, A. W. Jarvis, G. P. Martelli. M. A Mayo. M. D. Summers (eds), Virus Taxonomy - The Classification and Nomenclature of Viruses: Sixth Report of the International Commintee on Taxofomy of Viruses. Arch. Virol (Suppl 10) pp. 474-478

Brunt. A. A. R. H. Kenten (1973): Cowpea mild mottle a newly recognized viras infecting cowpeas (Vgha unguculata) in Ghana. Ann. Appl. Biol. 74, 67-74

Dubern, 1., M. Dollet (1981): Groundnut crinkle virus, a new member of the Carlavirus group. Phytopathol. Z, 101,337-347.

Hobbs, H. A., D. V. R. Reddy, R. Rajeshwari, A. S. Reddy (1987): Use of direct antigen coating and protein A coating ELISA procedures for detection of three peanut virases. Plani Dis. 71, 747-749.

lizuka, N., R. Rajeshwari, D. V. R. Reddy, T. Goto, V. Muniyappa. N. Bharathan, A. M. Ghanckar, (1984): Natural occurrence of a strain of cowpea mild mottle virus on groundnut (Arachis lypogaea) in India. Phylopathol. Z, 109, 245-253.

Iwaki, M., P. Thongmeearkom, Y. Honda, M. Promnin, N. Deema, T. Hibi, N. Izuka, C. A. Ong. N. Saleh (1986): Cowpea mild mottle virus occurring on soybean and peanut in Southeast Asian countries. Tech. Bull. Trop. Agric. Res. Center 21, 106-120. 
Jeyanandarajah, P., A. A. Brunt (1993): The natural occurrence, transmission, properties and possible affinities of cowpea mild mottle virus. J. Phytopathol. 137, 148-156.

Mahmoud, M. A., A. K. Osman, P. W. Nalyongo, A. Wakjira, C. David (1992): Groundnuts in Eastern Africa 1981-1990. In: S. N. Nigam (ed.), Groundnut - a global perspective, pp. 89 95, ICRISAT, Patancherw. A.P.502 324, India.

Reddy, D. V. R., A. F. Murant, G. H. Duncan, O. A. Ansa, J. W.
Demski, C. W. Khun (1985): Viruses associated with chloretic rosette and green rosette diseases of groundnut in Nigeria. Ann. Appl. Biol. $107,57-64$.

Storey, H. H., A. K. Ryland (1957): Viruses causing tosette and other diseases in groundnuts. Ann. Appl. Biol. 45, 318-326.

Walkey, D. G. A., A. A. Alhubaishi, M. J. W. Webb (1990): Plant virus diseases in the Yemen Arab Republic. Trop. Pest Manage. 36, 195206. 
This document is a scanned copy of a printed document. No warranty is given about the accuracy of the copy. Users should refer to the original published version of the material. 
This document is a scanned copy of a printed document. No warranty is given about the accuracy of the copy. Users should refer to the original published version of the material. 